\title{
Extensional Messinian basins in the Central Mediterranean (Calabria, Italy): new stratigraphic and tectonic insights
}

\author{
Alfonsa Milia ${ }^{1, *}$ and Maurizio M. Torrente ${ }^{2}$ \\ ${ }^{1}$ IAMC, CNR, Calata Porta di Massa, Porto di Napoli, 80100 Naples, Italy \\ 2 DST, Università del Sannio, Via Portarsa 11, 82100 Benevento, Italy
}

Received: 4 April 2018 / Accepted: 17 July 2018

\begin{abstract}
The direction of extension and the architecture of the Messinian basins of the Central Mediterranean region is a controversial issue. By combning original stratigraphic analysis of wells and seismic profiles collected offshore and onshore Calabria, we reassess the tectonic evolution that controlled the sedimentation and basement deformation during Messinian times. Three main deep sedimentary basins in the Calabria area record a Messinian succession formed by two clays/shales-dominated subunits subdivided by a halite-dominated subunit. The correlation with the worldwide recognized stratigraphic features permit to define the chronology of the stratigraphic and tectonic events. Three main rift basins that opened in a N-S direction have been recognized. On the contrary a fourth supradetachment basin opened toward the East. We found that the basin subsidence was controlled by two stages of activity of normal faults and that Messinian rift basins evolve in a deep-water environment. The overall pattern of extensional faults of the Central Mediterranean corresponds to normal faults striking parallel to the trench and normal faults striking at an oblique angle to the trench (Fig. 14). In particular in Campania and Calabria regions are present two rifts parallel to trench and an intervening rift orthogonal to the trench. We maintain that the recognized Messinian rift basins can be interpreted according to the "Double-door saloon tectonics".
\end{abstract}

\section{Introduction}

The pattern of faults and sediment-filled basins are used to reconstruct what happened during the extension of continents. In particular, continental rifts form with a variety of geometries, faulting patterns, and subsidence histories. For example, some rifts are narrow, like the Red Sea, and some are wide, like the Basin and Range Province. Some areas of apparently narrow rifting, such as metamorphic core complexes, do not subside locally (e.g., Lister and Davis, 1989), while some rifts, like those in East Africa, form deep basins even with modest amounts of extension. It has become accepted that the condition of the lithosphere at the time of rifting, its thermal structure, and crustal thickness, can have a profound effect on the tectonic development of a rift (e.g., Braun and Beaumont, 1989; Dunbar and Sawyer, 1989; Buck, 1991, Ziegler and Cloetingh, 2004; Corti et al., 2010; Jeanniot et al., 2016).

The Tyrrhenian rift-Apennines thrust belt system was first interpreted as a subduction rollback system bounded to the southeast by the Ionian Sea subduction zone by Malinverno and Ryan (1986). Several workers suggest a

* Corresponding author; alfonsa.milia@.iamc.cnr.it; torrente@unisannio.it backarc position of the Tyrrhenian Sea even if a clear documentation of the volcanic arc during the initial stages of the rifting is lacking.

The Tyrrhenian Sea (Fig. 1) was a polyphased rifting basin that gave rise to Serravallian-Quaternary extensional basins characterized by mantle exhumation during the Lower Pliocene (Kastens et al., 1987; Mascle and Rehault, 1990; Milia et al., 2013, 2017a). Even if the Pliocene-Pleistocene geological evolution of these extensional basins is well known (Horwáth et al., 1981; Sartori, 1990, 2003; Faccenna et al., 2007; Milia and Torrente, 2011, 2015a; Milia et al., 2017b; Torrente and Milia, 2013), the prePliocene rift architecture and paleogeography remain poorly understood. Recently the Tyrrhenian early-stage rifting (Serravallian-Tortonian) was interpreted as an upper plate extension (backarc and forearc extension) affecting both margins of Calabria (Milia and Torrente, 2014; Chen et al., 2015; Milia et al., 2017c). Though Messinian deposits have been recognized in the Tyrrhenian Sea (e.g. Malinverno et al., 1981; Gaullier et al., 2014) the geological documentation of the mode of extension during Messinian remains scarce as well as the paleogeographic reconstruction are rough. The Messinian salinity crisis is widely regarded as one of the most dramatic episodes of oceanic change of the past 20 or so million years (Hsü et al., 
1973; Hilgen et al., 1995). The study of the tectonic features affecting the Tyrrhenian region during the Messinian has important implications for the knowledge on the origin of the salinity crisis. Most hypotheses about the initiation of the Messinian salinity crisis agree that it resulted from a complex combination of tectonic and glacio-eustatic processes which progressively restricted and finally isolated the Mediterranean Sea from the open ocean (Clauzon et al., 1996; Butler et al., 1995; Vai, 1997). Krijgsman et al. (1999) argue in favour of a dominantly tectonic origin for the Messinian salinity crisis.

This study was led in Calabria (Fig. 2) that resulted the best locality to investigate the mode of extension during Messinian times. Though the Messinian successions basins outcropping in Calabria have been studied by several workers (Di Nocera et al., 1974; Van Dijk, 1990; Cavazza and De Celles, 1998; Zecchin et al., 2013), there is still no regional unified framework for the evolution of these sedimentary basins.

In this paper new outcomes on the stratigraphic architecture Messinian extensional basins overlying the Calabrian nappe stack and Serravallian-Tortonian covers are presented. The points we address are: (1) clarification of the basin infill stratigraphy and timing of sedimentation and deformation, (2) 3D architecture of the infill and faults in the Calabria area; (3) shed light on the issues regarding the style and directions of extensional deformation. In order to accomplish these goals we made a stratigraphic interpretation of seismic and borehole data; we also built a regional correlation between Messinian sub-basins located offshore and onshore Calabria and proposed a multi-stage kinematic model of rifting.

\section{Material and methods}

The Messinian basins of Calabria were investigated by means of the stratigraphic interpretation of deep boreholes located onland and on the continental shelf (Fig. 2; ViDEPI, 2009). We recognized several subunits of the Messinian stratigraphic succession using well logs, seismic facies calibrated by wells and outcrops stratigraphy described in the geologic maps of the studied areas. The interpretation of two sets of multi-channel seismic profiles located on the eastern margin of Calabria (Fig. 2) has been calibrated by the well stratigraphic analysis of the Messinian successions of Calabria. The first set corresponds to commercial profiles for hydrocarbon exploration (ViDEPI, 2009), whereas the second set consists of high-penetration profiles acquired during the exploration phase of the Deep Crust (CROP) project (www.crop.cnr.it). Our study uses two CROP offshore seismic sections (M4 and M5) of the Ionian Sea. We made use of Kingdom ${ }^{\circledR}$ software (copyright IHS Inc.) to build a Geographic Information System (GIS) seismic grid database, to do a geological interpretation of seismic profiles, and to perform 2-D models of stratigraphic horizons. Faults were interpreted on seismic reflection profiles (providing location and separation of these structures), mapped in a GIS environment, and displayed as lines on structure contour maps. Due to a relatively strict spacing between

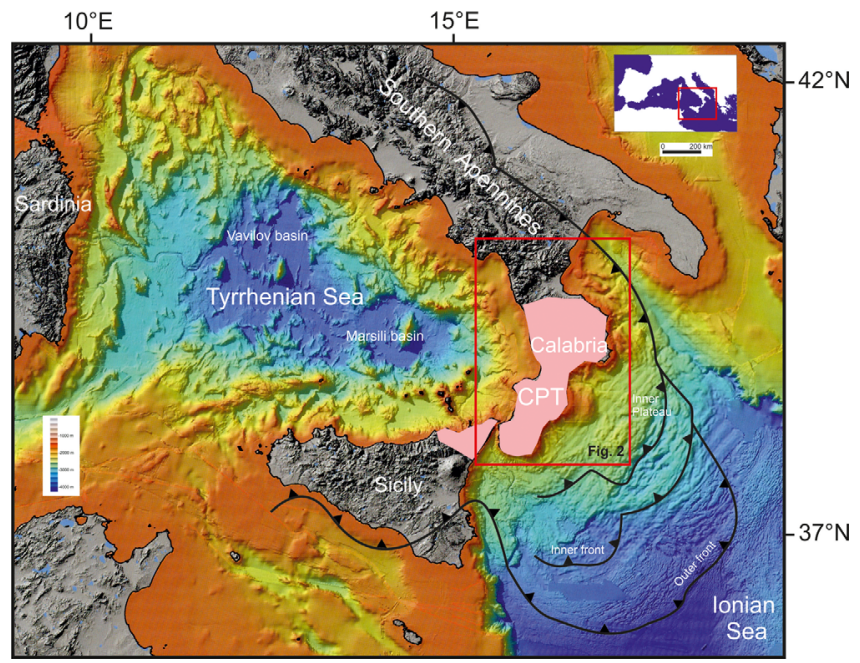

Fig. 1. (a) Morpho-bathymetric and tectonic map of Italy and nearby seas (Brosolo et al., 2012). CPT = Calabria-Peloritani terrane. Main tectonic features are from Capozzi et al. (2012), Jarsve and Pedley (2012), and Panieri et al. (2013).

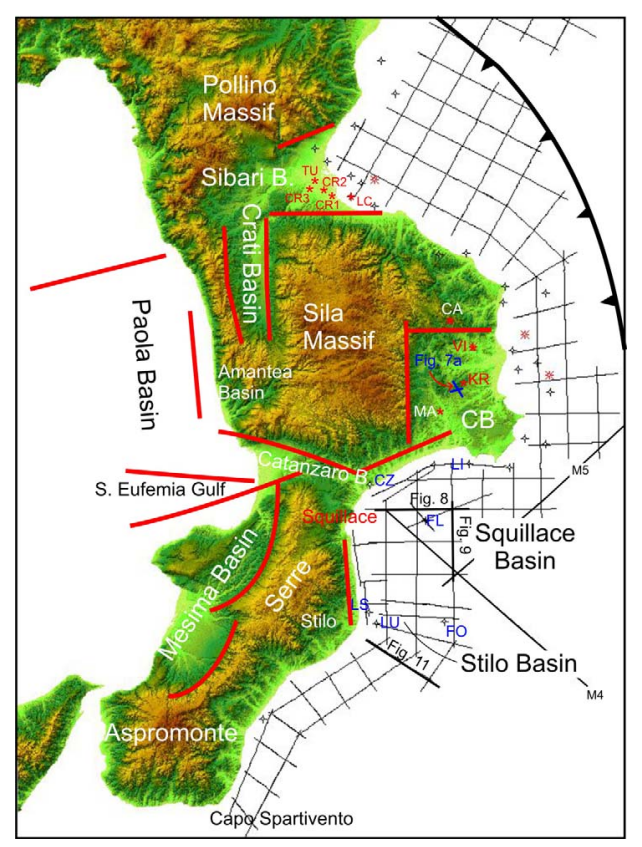

Fig. 2. Structural sketch of Calabria showing Neogene structural highs (Pollino Massif, Coastal Chain, Sila Massif and Aspromonte-Serre) and basins (Sibari B.-Crati B.-Amantea B., Paola B., S. Eufemia Gulf, Catanzaro B., Squillace Gulf, Mesima B., Stilo B. and Crotone B.). Red lines are normal separation faults. The analyzed boreholes and seismic grid are also displayed. Thick-line segments of the seismic tracks are shown in Figures 7-9 and 11. $\mathrm{CB}=$ Crotone Basin, LS = Luisa well, $\mathrm{FO}=$ Fosca well, $\mathrm{LU}=$ Luciana well, $\mathrm{FL}=$ Floriana well, $\mathrm{CZ}=$ Catanzaro well, $\mathrm{LI}=$ Liliana well, $\mathrm{MA}=$ Marcedusa well, $\mathrm{KR}=$ Crotone well, $\mathrm{VI}=$ Vitravo well, CA = Campana well, $\mathrm{LC}=$ Licia well, $\mathrm{CR}=$ Crati $3, \mathrm{TU}=$ Thurio well. Modified from Amodio Morelli et al. (1976) and Van Dijk et al. (2000). 
2-D seismic lines, it was possible to recognize and link major faults based on their geometry, dip direction, and amount of throw. The final step was the construction of the 3-D digital models using the Vu-PACK module that permits more accurate interpretations and controls opacity, color, and lighting of volumes, horizons, and faults. Seismic interpretation was made using seismic stratigraphy and sequence stratigraphy methods: seismic units are groups of seismic reflections, the parameters of which (configuration, amplitude, continuity and frequency) differ from those of adjacent groups. Sedimentary units were delineated on the basis of contact relations and internal and external configurations (e.g. Mitchum et al., 1977). Spina et al. (2011) reported $\mathrm{P}$-waves velocities $\left(V_{\mathrm{p}}\right)$ ranging between $1800 \mathrm{~m} / \mathrm{s}$ to $2300 \mathrm{~m} / \mathrm{s}$ for Pleistocene deposits and between $2300 \mathrm{~m} / \mathrm{s}$ and $3300 \mathrm{~m} / \mathrm{s}$ for Messinian deposits in the sonic logs of the Thurio and Ogliastrello wells. Following Milia et al. (2009) (Fig. 2), in the seismic depth conversion of the Sibari Basin we considered an average $V_{\mathrm{p}}$ value of $2000 \mathrm{~m} / \mathrm{s}$ and $3000 \mathrm{~m} / \mathrm{s}$, respectively for Pleistocene and Messinian deposits.

\section{Geological framework}

The Calabria terrane corresponds to a thrust pile made up of: higher pre-Mesozoic poly-metamorphic nappes (comprising large sheets of Hercinian crystalline basement of the Sila and Aspromonte-Serre massifs); intermediate Mesozoic to Cenozoic oceanic units; Lower Apennine-Maghrebian units Triassic-early Miocene in age (Amodio Morelli et al., 1976; Monaco et al., 1998). The Calabria terrane migrated southeastwards in response to the subduction of the Ionian oceanic lithosphere along a deep and narrow, W-dipping Benioff zone (Malinverno and Ryan, 1986; Bonardi et al., 2001; Sartori, 2003; Faccenna et al., 2007). The offshore external region of the Calabria terrane displays a thick and wide accretionary wedge with a rugged topography the sea floor of the Ionian Sea from the Malta to the Apulia escarpments, and is characterized by an active front in the Ionian abyssal plain (e.g. Panieri et al., 2013).

The movement toward the SE caused the fragmentation of the arc in individual blocks and the development of basins located along both the Ionian and the Tyrrhenian sides of Calabria (Knott and Turco, 1991; Spina et al., 2011). The Calabria nappe stack is interrupted by several Neogene basins (Crati, Mesima, Sibari, Catanzaro, S. Eufemia Gulf, Squillace Gulf; Fig. 2) which origin is matter of debate. The Late Cenozoic kinematics and the southeast migration of the Calabria terrane were interpreted as linked to the activity of arc-perpendicular strike-slip faults (e.g. Rossi and Sartori, 1981; Rehault et al., 1987; Turco et al. 1990; Knott and Turco, 1991; Van Dijk and Okkes, 1991; Vai, 1992; Tansi et al. 2007; Del Ben et al., 2008). Ghisetti and Vezzani (1981) and Milia and Torrente (2015b) reported the opening, after nappe emplacement, of postorogenic extensional basins during the activity of Tortonian and Messinian normal faults in Calabria. On the contrary the Crotone Basin has been interpreted as a fore-arc basin (e.g. Minelli and Faccenna, 2010; Capozzi et al., 2012; Reitz and Seeber, 2012) and is composed of relatively undeformed middle-upper Miocene to middle Pleistocene deposits unconformably covering the Calabria nappe stack. Although its stratigraphy was the subject of many papers (e.g. Roda, 1964; Van Dijk, 1994; Capozzi et al., 2012; Reitz and Seeber, 2012; Massari and Prosser, 2013) the timing and kinematics of basin formation remain uncertain. The Catanzaro and Squillace Gulf basins have been interpreted as pull-apart basins (e.g. Rossi and Sartori, 1981; Tansi et al. 2007; Del Ben et al., 2008; Capozzi et al., 2012) or extensional basins (e.g. Turco et al., 2013).

The Neogene Crotone Basin, developed along the Ionian side of Calabria, began to open between Serravallian and Tortonian times, and its tectonic history was characterized by a dominant extensional tectonic regime (Roda, 1964; Van Dijk, 1990; Massari and Prosser, 2013). Recently the recognition of deep basins, Serravallian-Tortonian in age, offshore the Ionian margin of the Calabria and their correlation with coeval sedimentary basins of the Central Mediterranean suggested a geodynamic framework characterized by a fore arc extension linked to a fixed overriding plate (Milia and Torrente, 2014; Chen et al., 2015; Milia et al. 2017c).

The Messinian succession of the Crotone Basin overlies Serravallian to Tortonian deposits that are up to $200 \mathrm{~m}$-thick. In the outcrops of the Crotone area (Servizio Geologico d'Italia, 2010) a Messinian pre-evaporitic succession covers in continuity the Tortonian succession, evolving upward to the Tripoli Fm and Stromatolitic Limestone Fm (Fig. 3). An important unconformity affects the Messinian deposits and the substrate, and it is in turn covered by coarse grained clastic deposits. Toward the East are present marine clays with thin strata of sands or conglomerates that include selenitic gypsum that lies dispersed in the sediments or forms layers. Resedimented blocks of gypsum are present in this succession. Within the clays succession are present strata of halite (e.g. at the Cufalo valley). This latter is covered by a heterogeneous, mostly siliciclastic deposit locally containing clastic gypsum (Petilia Policastro Fm; Fig. 3; Massari and Prosser, 2013). The upper part of the Messinian succession is made up of sands and conglomerates interlayered with clays (Carvane Fm).

Southward in the Squillace area (Fig. 3) (Servizio Geologico d'Italia, 2016), calcarenites and calcirudites lies unconformably on the Tripoli succession. Toward NE of Squillace, a succession of clays interlayered with strata of gypsum outcrops. In the area have been documented E-W/WNW-ESE and N-S normal fault infra-Messinian in age that affect the Tripoli succession.

Onshore Stilo (Fig. 3) the Miocene succession has been described by Cavazza and De Celles (1998). There a stratigraphic unit Messinian in age, made up of a thin pelite section with local limestone-gypsum (Unit 1 of Cavazza and De Celles, 1998) conformably overlies the Serravallian-Tortonian sequence. Both Serravallian-Tortonian and older Messinian units are tilted, eroded and covered in unconformity by younger Messinian clastics showing a transgressive trend from conglomerates to clays (Unit 2 of Cavazza and De Celles, 1998). 


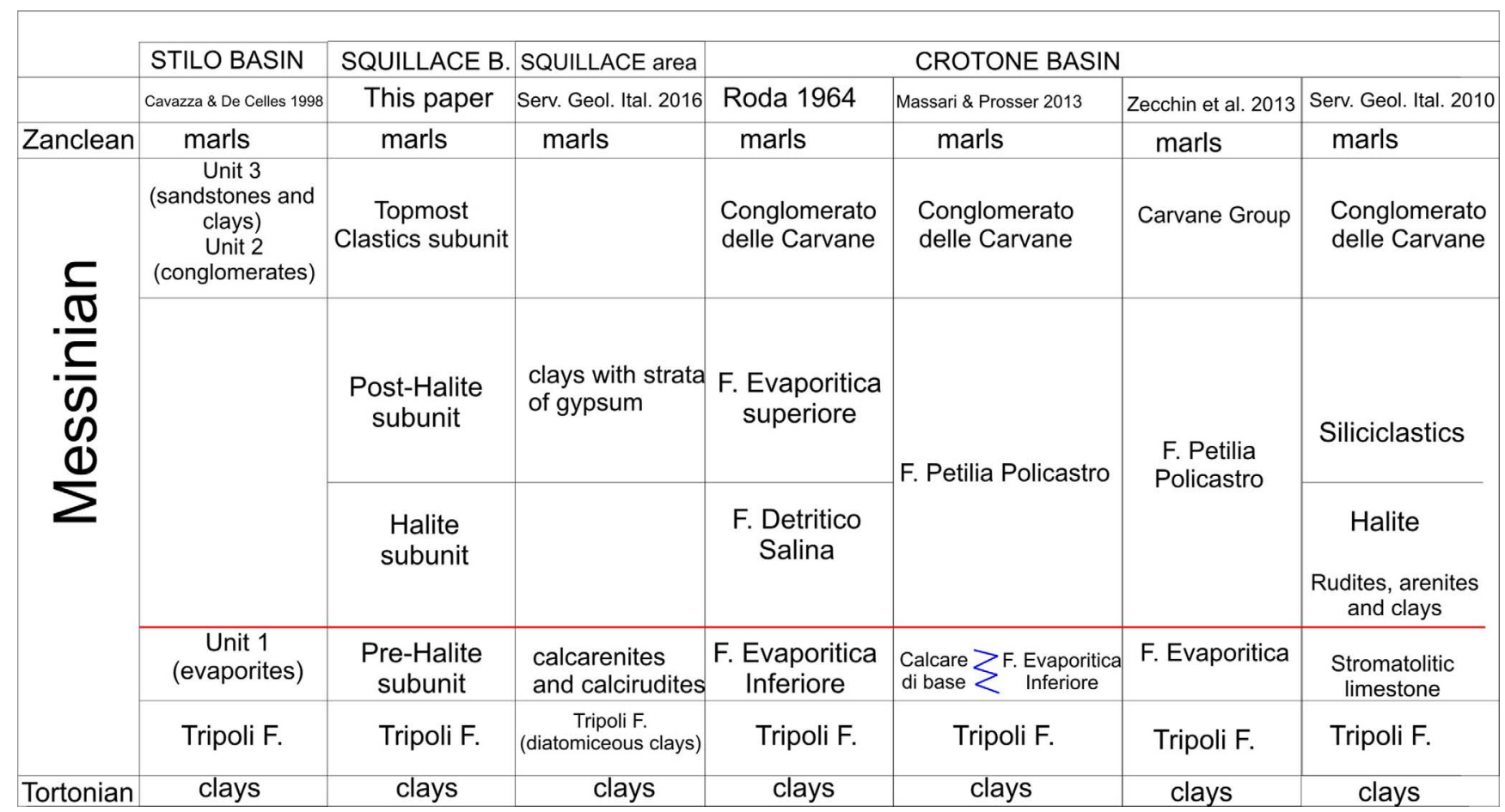

Fig. 3. Stratigraphic scheme of the Messinian succession, with indication of formational names adopted by previous authors and in this study.

\section{Stratigraphy and basin architecture}

The basin analysis of well logs and seismic profiles collected in the eastern part of Calabria was performed, from North to South, to study four Messinian sedimentary basins: Sibari Basin, Crotone Basin, Squillace Basin, and Stilo Basin (Fig. 2). The deepest well (Campana well; Fig. 4) of the Calabria area drilled the whole Calabria nappe pile unconformably covered by Miocene deposits. Based on the stratigraphic features the Messinian succession has been subdivided into four parts: pre-halite subunit; halite subunit; post-halite subunit; topmost clastic subunit (Fig. 5). These subunits can be recognized in well logs, seismic facies calibrated by wells and outcrops stratigraphy.

\subsection{Sibari Basin}

The Sibari Basin is bounded to the North by the Pollino Massif (mainly made up of oceanic-derived units that overlain Apennine carbonate platform units) and to the South by the Sila Massif (mainly built of Calabride basement units overlying oceanic-derived units that also outcrop in a tectonic window to the north). In the Sibari Basin the Calabria terrane, drilled at Crati 3 and Licia wells, is unconformably covered by Messinian deposits characterized, from older to younger, by (Figs. 4 and 5): (i) Pre-halite subunit made up of coarse sandstones at Thurio well (119 m-thick) and Licia well ( $82 \mathrm{~m}$-thick) overlain by marly clays containing up to $10 \mathrm{~m}$-thick gypsum strata and coarse sands and conglomerates layers; the pre-halite subunit features thicknesses ranging between $625 \mathrm{~m}$ (Crati 3 well) and to $42 \mathrm{~m}$
(Thurio and Licia wells). The thickness of the marly clays increases in the area where the basal coarse sandstone is absent, thus suggesting that they were deposited in a distal part respect to the slope margin of the basin as the coarse sandstones represent the area proximal to the slope of the basin margin. (ii) Intermediate subunit, consisting of halite and anhydrite/gypsum interlayered with clays, that displays thicknesses ranging between $543 \mathrm{~m}$ (Thurio well) and $29 \mathrm{~m}$ (Crati 2 well); the subunit thickness increases proportionally to that of the basal coarse sandstones; (iii) Post-halite subunit is made up of clays and sands with gypsum inter-layered, thin strata of sandstones and 10-20 $\mathrm{m}$-thick strata of conglomerates deposited are present in the Thurio well.

The thickness of the post-halite subunit is higher where the basal coarse sandstones were laid down. The Messinian succession shows the maximum thickness $(1264 \mathrm{~m})$ at Thurio well and is covered by Lower Pliocene (Crati 2 well) or unconformably by Lower Pleistocene deposits.

Two orthogonal geologic sections (Fig. 6) have been reconstructed in the Sibari Basin using seismic sections calibrated by well logs data. The borehole stratigraphies of the NW-SE section reveal in the northern sector a high of the basement substrate (outcropping few $\mathrm{km}$ northwards) and Messianian wedge thickening northwards. These data permitted us to recognize an asymmetrical extensional depression of the substrate bounded to the north by a south-dipping master fault (\#1 in Fig. 6A) that was active during Messinian times. The WSW-ENE section displays a gradual thinning of the deposits toward the margin of the basin suggesting that it represents a strike section of the 


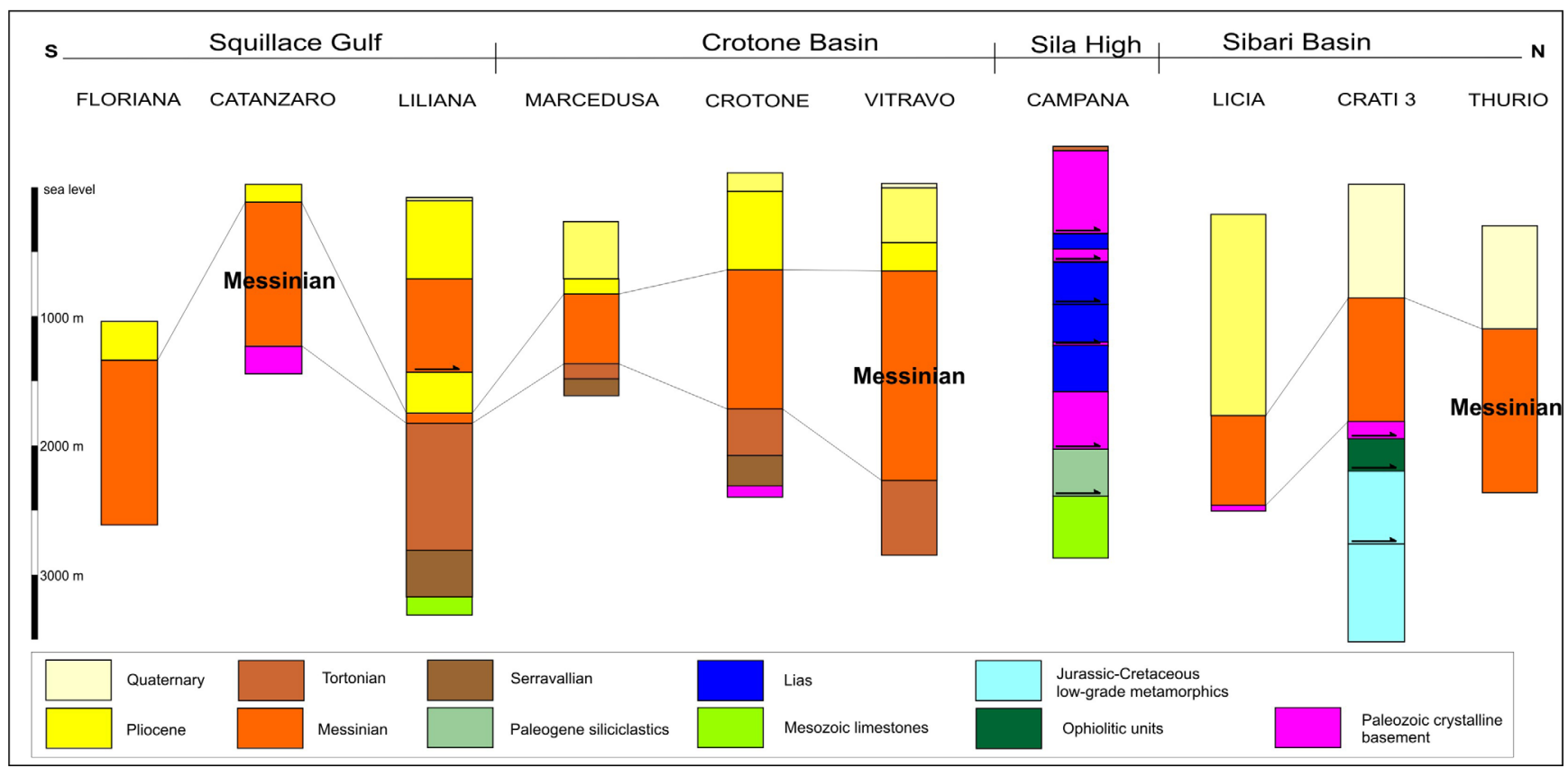

Fig. 4. Stratigraphic successions of deep wells of the Calabria region.

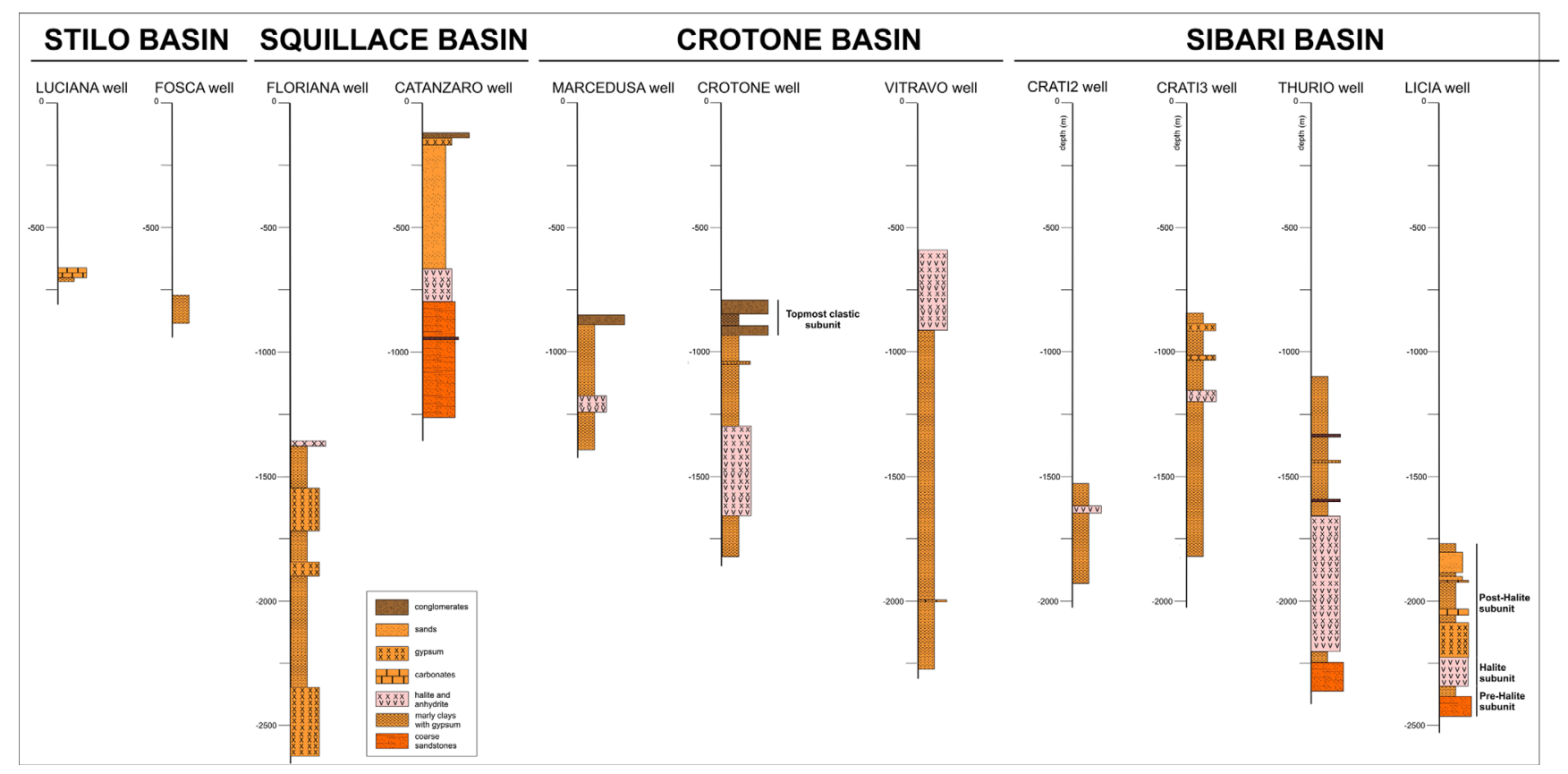

Fig. 5. Stratigraphic logs of the Messinian deposits of the Calabria basins.

Messinian basin. The peculiar features of the Thurio well succession (coarse-grained deposits at the base, thickness of the salt, thin strata of sands and conglomerates in the upper part of the succession) suggest that this well drills the axial part of the basin close to active boundary fault. On the contrary the southern margin of the basin, mainly made up of clay deposits, is affected by hanging wall gradual subsidence and the absence of Messinian faults in the southern margin. Finally, the lack of a clear coarse-grained succession at the top, suggests a relatively open sea and underfilled sedimentary basin during the late Messinian stage. The Quaternary succession of the Sibari Basin shows, respectively, a wedge thickening eastwards on the WSW-ENE section and a subsiding basin with subparallel strata on the NW-SE section. On the southern part of the NW-SE section the stratigraphies of the wells Crati 1 and Crati 2 documents a northward lowering of the Messinian top and a thickening of the Pleistocene deposits toward 

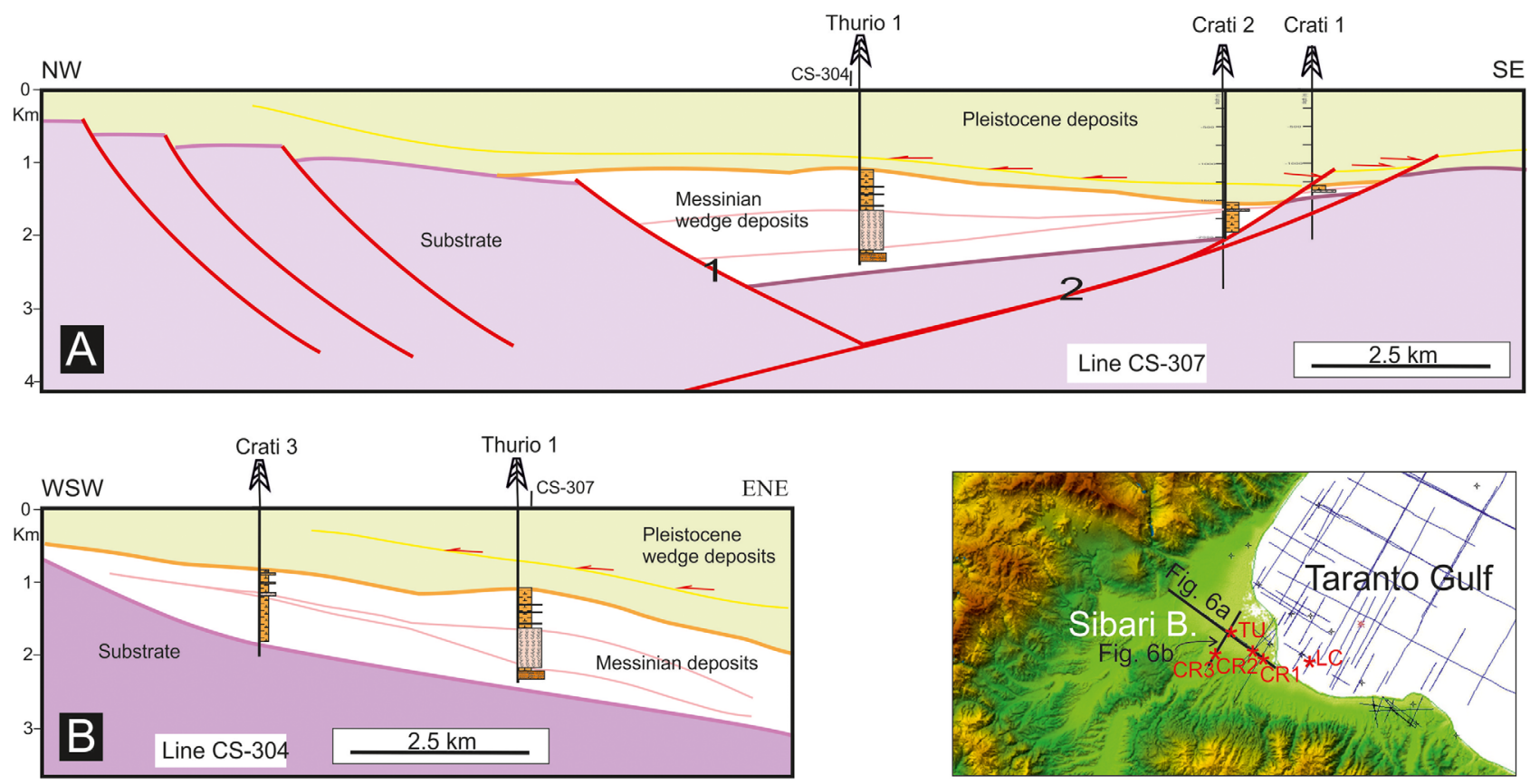

Fig. 6. Geological sections of the Sibari basin. \#1 and \#2 are normal faults. For the depth conversion of Pleistocene and Messinian seismic units we assumed, respectively an average $V_{\mathrm{p}}$ of 2000 and $3000 \mathrm{~m} / \mathrm{s}$.

the south; both these data lead us to identify a couple of Pleistocene north-dipping faults (\#2 in Fig. 6A).

\subsection{Crotone Basin}

The Crotone Basin is characterized by a Miocene sedimentary succession, formed by a Serravallian coarse-grained succession, Upper Tortonian clays (Ponda Fm) and a very thick Messinian succession (e.g. Vitravo, Crotone and Marcedusa wells; Fig. 4). The Messinian succession presents (Fig. 5), from older to younger: (i) a basal subunit, made up of silty clays and sands levels with some anhydrites, that thickens dramatically northwards, from $152 \mathrm{~m}$ in the southern part (Marcedusa well) to $1342 \mathrm{~m}$ in the northern part (Vitravo well); (ii) a subunit consisting of halite with some anhydrites; (iii) a post-halite subunit made up of clays with levels of sandstones and conglomerates (Marcedusa and Crotone wells); (iv) a topmost clastic subunit made up of coarse deposits and polygenic conglomerates (Carvane Fm; Marcedusa and Crotone wells). Notably in the northern part of the basin (Vitravo well) the upper and topmost Messinian units are absent and Lower Pliocene clays unconformably overlie the intermediate halite unit.

A different tectono-stratigraphic behavior of the northern and southern sectors of the Crotone Basin is documented by: lack in the northern sector (Vitravo well) of the upper and topmost Messinian units; abrupt change of depth of the base of the halite unit (958 and $1661 \mathrm{~m}$, respectively at Vitravo and Crotone wells). This difference is consistent with the Messinian activity of a syn-depositional normal/transtensional fault located between the Vitravo and Crotone wells. Other Messinian faults are imaged close to the Crotone well by a NNW-trending seismic section
(Fig. 7) displaying a set of growth normal faults down throwing the fault blocks to the south. The absence of these faults in the ENE-WSW perpendicular section, that shows not faulted Neogene deposits, lead us to interpret an approximately E-W trend of these normal faults of the Crotone Basin (Fig. 7). Notably Van Dijk (1990) already reported E-W growth normal faults of Messinian age in the Crotone Basin.

\subsection{Squillace Basin}

Southward in the Squillace Basin the outcrops and wells reveal two distinctive Messinian facies in the stratigraphic successions as in the Catanzaro and Floriana wells. The Catanzaro well, drilled along the coast, encountered Messinian deposits that repose above a pre-Triassic metamorphic basement (Fig. 4). The Messinian succession (Fig. 5), with a total thickness of $1080 \mathrm{~m}$, is made up of coarse sandstone and sands with clays levels containing anhydrite and an inter-layered polygenic conglomerate, $400 \mathrm{~m}$ thick. The basal succession is capped by the halite $(130 \mathrm{~m})$ that in turn is covered by clays, sands and upward silty clay with anhydrite $(530 \mathrm{~m})$. The succession terminates with $20 \mathrm{~m}$-thick conglomerate of the Carvane Fm. Offshore the Floriana well (Fig. 5) encountered a 1275-thick succession of Messinian deposits made up, from the base, of $280 \mathrm{~m}$ of gypsum with interlayered thin levels of clays and fine sands followed by a thick succession of clays with sand levels interlayered by three thick strata of gypsum/anhydrite. Some halite layers are present at the top of the succession. The interpretation of a seismic line (Fig. 8) in the Squillace Basin shows different seismic facies in correspondence of these two wells. In particular, we can observe a chaotic seismic facies (f1) 


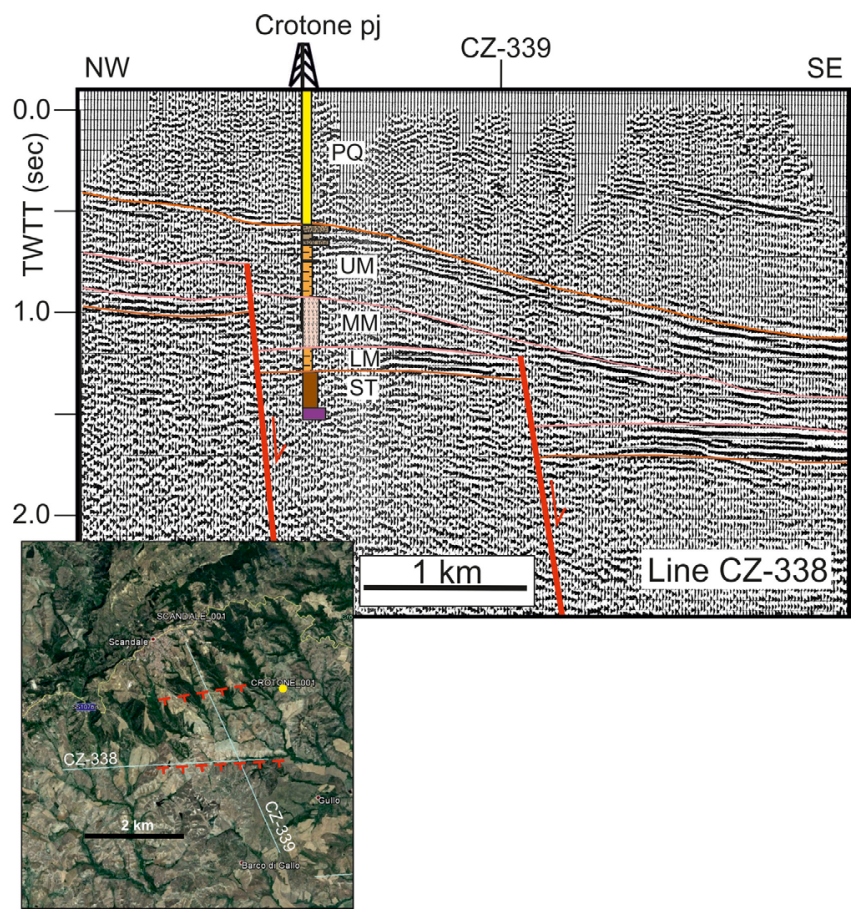

Fig. 7. Interpreted seismic section calibrated by the Crotone well showing Messinian normal faults. ST $=$ Serravallian-Tortonian, $\mathrm{LM}=$ Messinian Pre-Halite subunit, $\mathrm{MM}=$ Messianian Halite subunit, $\mathrm{UM}=$ Messinian Post-Halite and Topmost clastic subunits, $\mathrm{PQ}=$ Pliocene-Quaternary. Lower inset displays a fault sketch map and the location of seismic lines CZ-338 and CZ-339 and Crotone well.

that changes abruptly to a parallel seismic reflectors with very good continuity (f2), characterized by three strong reflectors interlayered in a succession with very high amplitude. The sudden facies and thickness change of Messinian deposits suggest the occurrence of a post-Messinian transcurrent fault between these two sectors (Fig. 8). The interpretation of a N-S seismic line (Fig. 9) crossing the Squillace Basin displays a couple of $\mathrm{E}-\mathrm{W}$ normal faults and a central graben. In particular the southern sector is characterized by a strong thickness change of the Messinian deposits thus suggesting a normal fault activity during Messinian. Younger folds affect the lower part of the Plio-Quaternary succession (Fig. 9).

The interpretation of the seismic grid calibrated by well logs discloses a complete Messinian succession in the Squillace Basin. In particular the isochronous map of this succession displays (Fig. 10B) a basin architecture characterized by a thickness maximum reaching $1.7 \mathrm{~s} \mathrm{(twtt)} \mathrm{east}$ of Squillace (Squillace Basin) bounded by a couple of approximately E-W normal faults.

\subsection{Stilo Basin}

Offshore Stilo, thin Messinian deposits overlying Serravallian-Tortonian deposits have been encountered in the Luisa, Luciana and Fosca wells (Fig. 4). The Fosca well shows a 114 m-thick Messinian succession made up of silty clays covered unconformably by Lower Pliocene clays. The isochronous map of the Messinian succession of the Stilo Basin (Fig. 10B) displays two maxima ( $>1.3$ and $>1.1 \mathrm{~s}$ of twtt) bounded by a couple of approximately N-S normal faults. A WNW-ESW oriented seismic reflection profile crossing the Stilo Basin (Fig. 11) reveals low-angle normal faults displacing the substrate and the Miocene succession. The Lower Messinian unit, only present in the eastern sector of the basin, is characterized by fault-bounded wedges. The Upper Messinian unit instead presents sub-horizontal strata, has a broader distribution, and covers unconformably substrate, Serravallian Tortonian deposits and Lower Messinian unit. This architecture records the activity of a Messinian supradetachment basin that produced a rotation of distal blocks and Messinian erosional surface, and the unroofing and erosion of the substrate.

\section{Tectonic model of the Messinian sedimentary basins}

The Messinian is one of the most peculiar geologic periods in the Mediterranean area because the Messinian Salinity Crisis (MSC) is widely regarded as one of the most dramatic episodes of oceanic change over the past 20 or so million years. The interpretation of well data, seismic reflection profiles and the correlation with outcrops permitted us to investigate the thick Messinian succession along the Ionian margin of the Calabria region. The peculiar features of these Messinian sedimentary basins have very important stratigraphic and tectonic implications for the evolution of the Central Mediterranean. The pre-MSC succession corresponds in outcrop to Tortonian clays passing gradually to the Lower Messinian Tripoli Fm. This succession is present in the northern area of the Crotone Basin and probably reflects a continuity in the sedimentation with the deep basin forming since Serravallian times (Milia and Torrente, 2014). The stratigraphic succession deposited during the MSC and the key surfaces recognized in the Calabria basins have been correlated with a new chronostratigraphic scheme (Roveri et al., 2016 and bibliography therein) of the Messinian succession characterized by main unconformities and facies coeval in the whole Mediterranean (Fig. 12). In particular, that scheme illustrates the Primary Lower Gypsum (PLG subunit), that developed in the shallow water basin, passing laterally in deep basin to clays/ shales with very thin calcareous strata in the lower part of the succession. These facies, deposited between the onset of the MSC (5.97 Ma) and the erosional unconformity (MES) dated at 5.60 Ma, have been described in the Piedmont Basin, northern Italy (Dela Pierre et al., 2011). The unconformity characterized by subaerial erosion at the basin margin is covered by a clastic succession, made up of calcareous breccia, gypsum rudite and arenite (RLG subunit) passing laterally and upward to halite deposition (5.60-5.54 Ma). At 5.54 Ma in the deep basin, above the salt succession, occurred the deposition of clay/shale interlayered with gypsum (UG1 subunit) that since $5.42 \mathrm{Ma}$ evolved upward to an increase in fluvial discharge facies (UG2 subunit). 


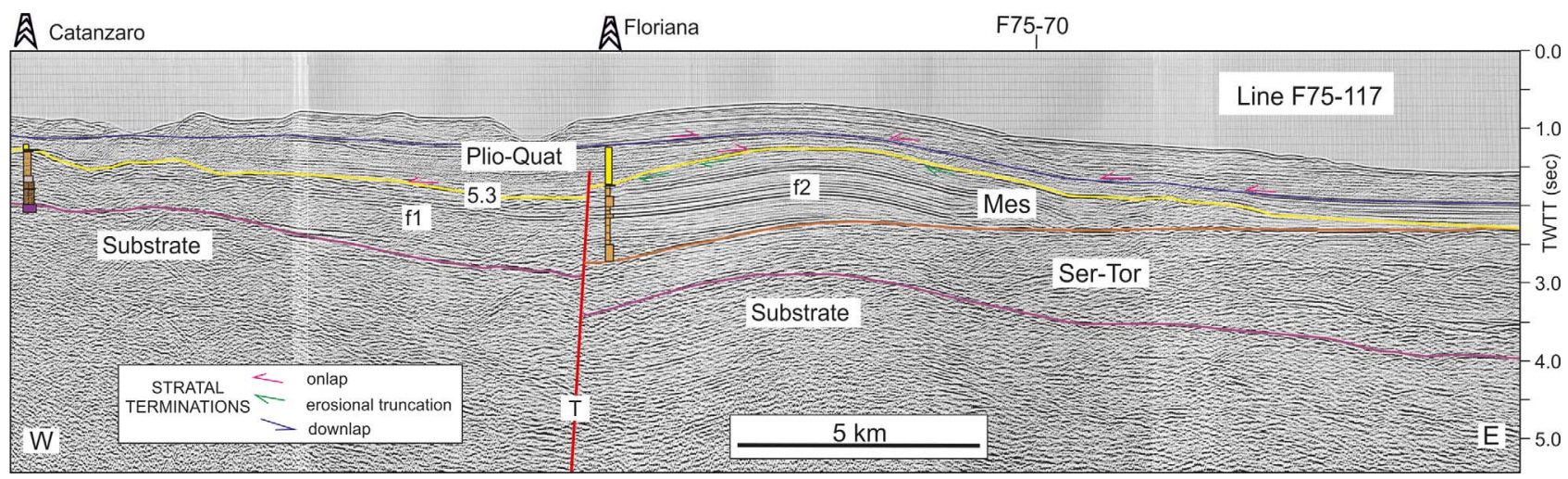

Fig. 8. Interpreted seismic section calibrated by the Crotone and Floriana wells. Ser-Tor = Serravallian-Tortonian, Mes $=$ Messinian, $\mathrm{f} 1=$ chaotic seismic facies, $\mathrm{f} 2=$ parallel reflectors seismic facies, $\mathrm{T}=$ transcurrent fault. For seismic line location see Figure 2.

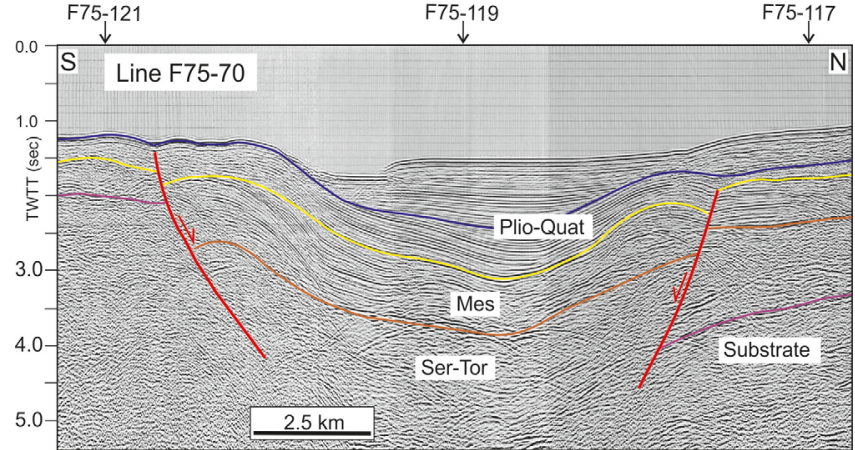

Fig. 9. Interpreted seismic section of the Squillace Basin. Ser-Tor $=$ Serravallian-Tortonian, Mes $=$ Messinian. For seismic line location see Figure 2.

The deep wells drilled in Calabria reveal that a thick pre-Halite succession is mainly made up of clays that in the basal part of Vitravo well contains some thin strata of limestone; whereas in the Floriana well are present thick and very thick strata of gypsum interlayered in clays. Following the Messinian stratigraphic sketch of Roveri et al. (2016), the clay-rich facies that lies below the halite deposits can be interpreted as the deep basin/distal facies of the PLG subunit (Fig. 12). An important erosive surface, recognized onshore at the margin of the basin, affects both the substrate and the Miocene succession. This surface is covered by a thick clastic succession (Servizio Geologico d'Italia, 2016). This Messinian clastic facies reposes on the Calabride substrate and terminates upward with the halite deposit in the Catanzaro well. This subunit can be interpreted as RLG subunit, and in particular the clastic succession that passes upward and laterally to the halite deposits. Upward the halite deposit is covered by a succession mainly made up of clay with gypsum and interlayered clastic deposits. These latter have been interpreted as turbidite deposits that fill the Crotone Basin (Zecchin et al., 2013). Finally, in the Crotone Basin the succession is covered by conglomerates and sands interpreted as shallow-water
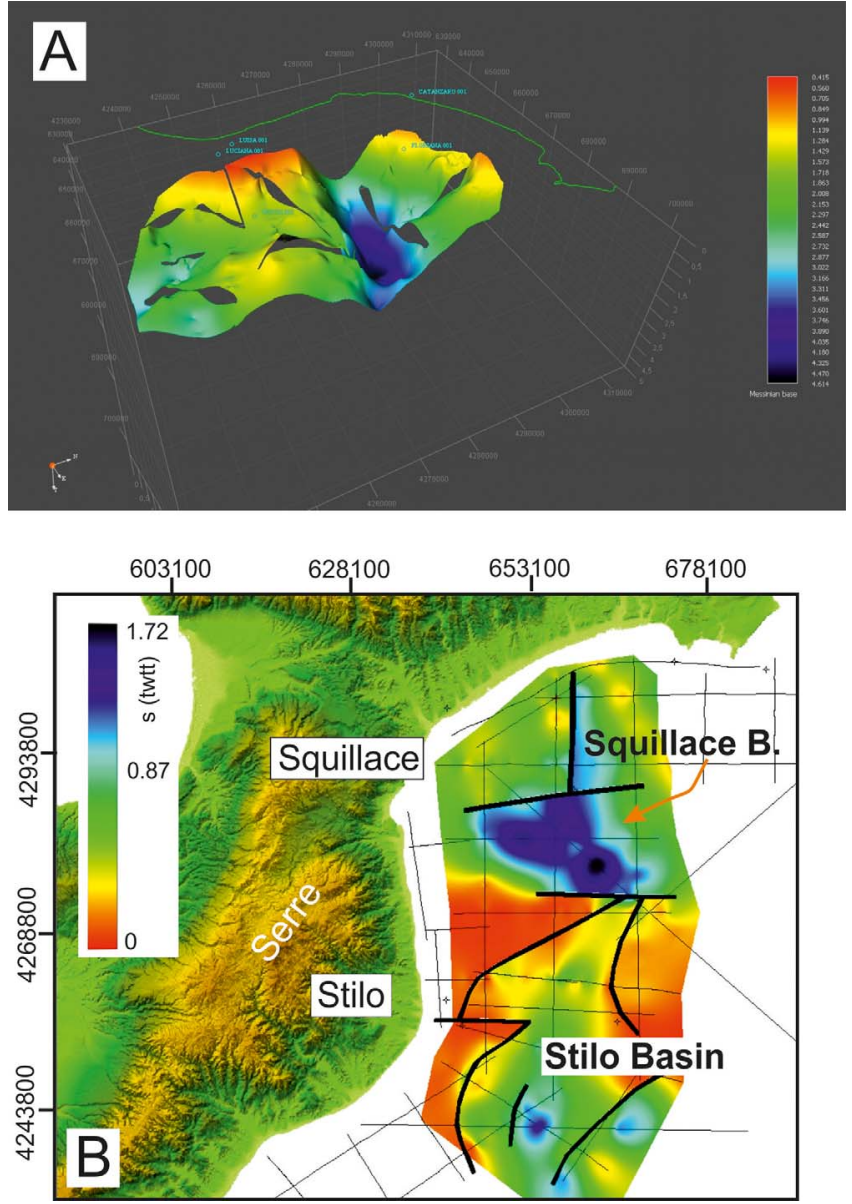

Fig. 10. (A) The 3D digital model inserted into the spatialoriented grid of the base of the Messinian unit. The green line corresponds to the Calabrian coast. View is toward the West. (B) Isochron map of the Messinian deposits. Map coordinate system: UTM, WGS84.

facies. The post-halite succession can be correlated respectively to the UG1 and UG2 subunits. 


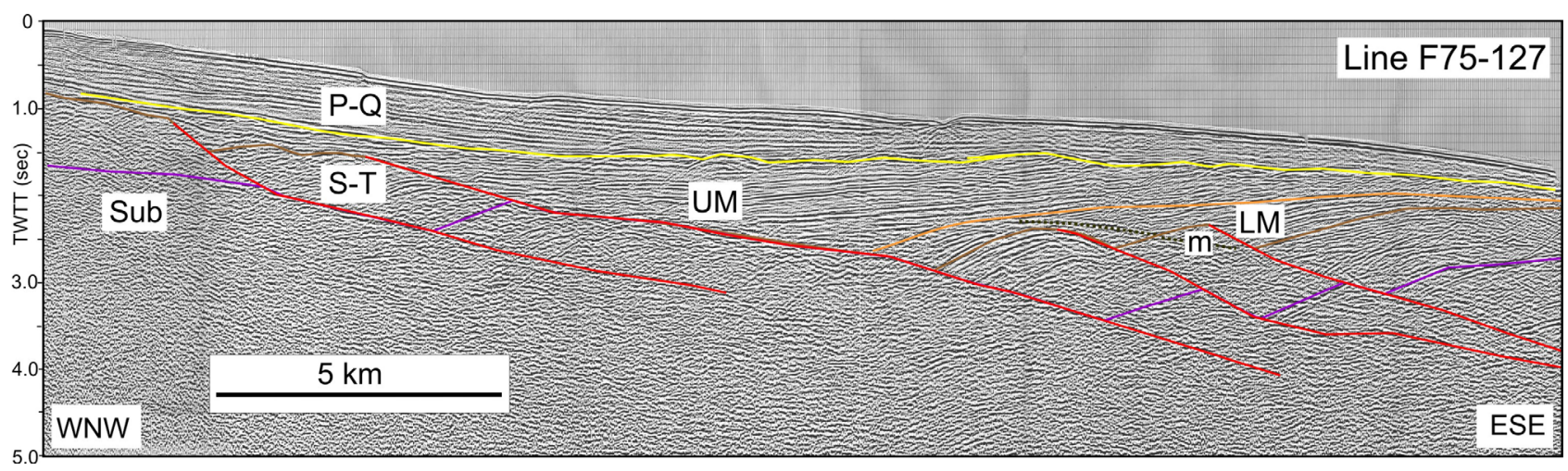

Fig. 11. Interpreted seismic section across the Stilo Basin. Sub = substrate S-T $=$ Serravallian-Tortonian, LM $=$ Lower Messinian, $\mathrm{UM}=$ Upper Messinian, P-Q = Pliocene-Quaternary, $\mathrm{m}=$ sea-floor multiple. For seismic line location see Figure 2.

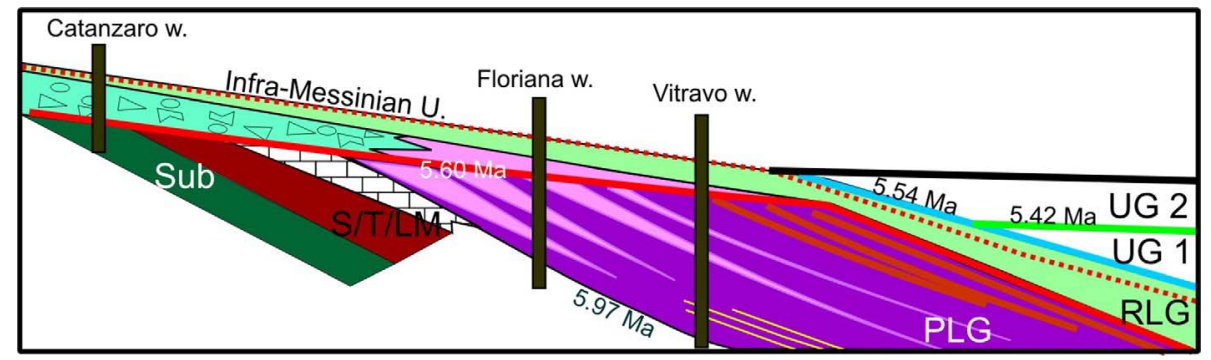

Fig. 12. Stratigraphy of the Catanzaro, Floriana and Vitravo wells within the chronostratigraphic framework of the Messinian in the Mediterranean (modified from Dela Pierre et al., 2011; Roveri et al. 2016). Sub = Substrate, S/T/LM = Serravallian, Tortonian, Lower Messinian, PLG = Primary Lower Gypsum, RLG = Resedimented Lower Gypsum, UG1 = Upper Gypsum 1, UG2 = Upper Gypsum 2 .

The widening of the extensional area during Messinian times is documented by the faults that displaced and uplifted substrate blocks which erosion produced clastic deposits (Sibari and Squillace Basins). Although the Sibari basin developed in deep-water environment, on the contrary the Stilo Basin (Cavazza and De Celles, 1998) was characterized by a basal thin pelite section with local limestone-gypsum unconformably covered by alluvial conglomerates that witness a tectonic uplift.

The original geometric relationships between these Messinian sedimentary basins have certainly been altered by the following transcurrent/transpressive tectonics that could have caused lateral dislocations (Van Dijk and Okkes, 1991; Van Dijk, 1994; Tansi et al., 2007; Spina et al., 2011; Milia et al., 2017d). Nevertheless, to investigate the crustal architecture of Messinian basins of Calabria we built a N-S geological sketch, orthogonal to E-W normal faults documented onshore and offshore, and made a stratigraphic correlation between the Messinian subunits (Fig. 13).

The reconstructed architecture of the Messinian subunits is useful to establish the synchronicity of sedimentary facies and to date fault activity. The Messinian extension affected both marine and emerged areas and produced the Sibari, Crotone and Squillace basins (Fig. 13). The identification of several stratigraphic markers permitted us: to recognize a dramatic increase of basement depth toward the north (Crotone and Sibari basins); to identify the basin-boundary faults; to recognize an asymmetric tectonic subsidence.

The architecture of the Messinian basins reveals two rift stages and growth faults formed at 6.0 Ma and 5.54 Ma. These tectonic stages are well documented in the Crotone Basin displaying a complex half-graben basin formed by two sectors: a northern one (Vitravo well) featuring prehalite and halite subunits; a southern one (Crotone well) featuring instead pre-halite, halite and post-halite subunits. This stratigraphic architecture suggests that the first stage of subsidence produced a normal fault located north of Vitravo well, whereas the second stage affected the southern sector of the basin associated to the activity of a normal fault positioned between Vitravo and Crotone wells. The Stilo Basin reveals a different history characterized by the presence of low-angle detachment faults that extended the area eastwards and produced the uplift of basement footwall blocks uncoformably covered by upper Messinian conglomerates (unit 2 of Cavazza and De Celles, 1998). Even if growth strata record a Messinian fault activity, the footwall denudation probably occurred before $5.42 \mathrm{Ma}$ (deposition of the UG2 subunit of Roveri et al., 2016).

The opening of sedimentary basins during the Messinian time has been well documented on the western margin of the Tyrrhenian Sea since the ODP project (Kastens et al., 1987). On the Eastern Tyrrhenian margin (northern Campania), a Messinian succession, approximately 


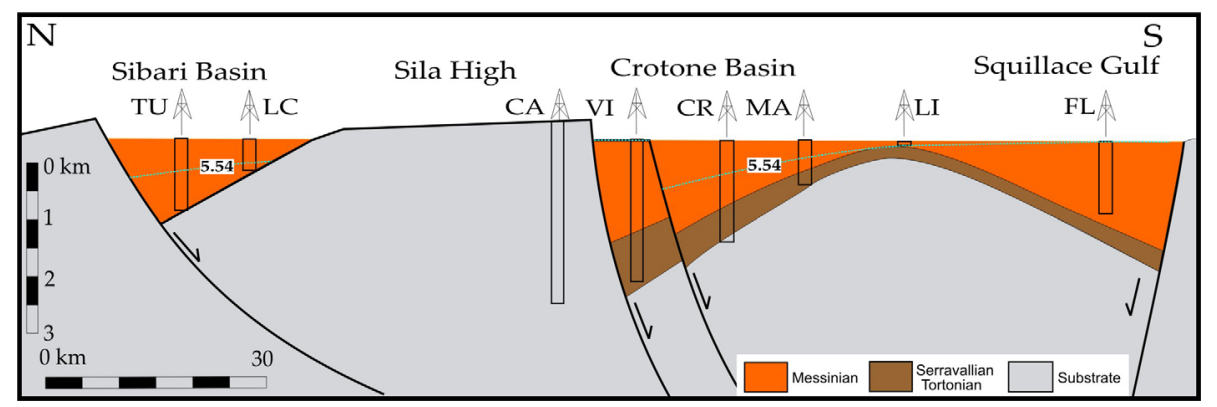

Fig. 13. Geological sketch across the Calabria Messinian basins. $\mathrm{FL}=$ Floriana well, $\mathrm{LI}=\mathrm{Liliana}$ well, $\mathrm{MA}=\mathrm{Marcedusa}$ well, $\mathrm{CR}=$ Crotone well, $\mathrm{VI}=$ Vitravo well, $\mathrm{CA}=$ Campana well, $\mathrm{LC}=$ Licia well, $\mathrm{TU}=$ Thurio well.

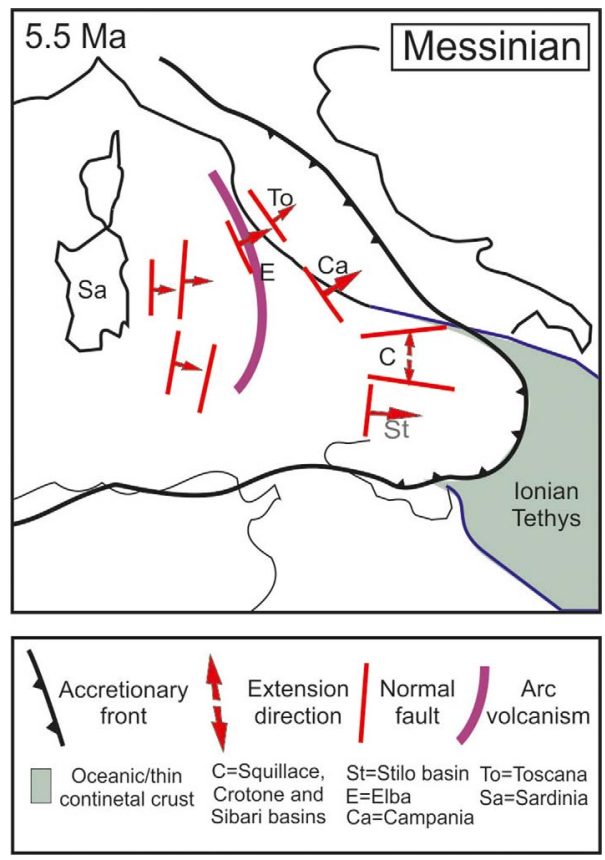

Fig. 14. Kinematic sketch of the Central Mediterranean orogenic system during Messinian times, including volcanic arc, nappe's transport direction, extension direction, and strike-slip faults. Approximate location of the magmatic arc from 5.5 Ma as suggested by Rosenbaum and Lister (2004).

1000 m-thick, formed in an extensional regime (Cosentino et al., 2006). Further extensional Messinian basins are reported off Tuscany (Sarti, 1995; Pascucci et al., 1999), and off Calabria (Mattei et al. 2002).

The basin analysis and basin architecture supplied here for Calabria Messinian basins and the correlation with coeval Tyrrhenian basins furnish additional elements to reconstruct a new paleo-tectonic framework of the extensional processes occurred during Messinian in the Central Mediterranean (Fig. 14). In particular N-S trending normal faults produced rift basins offshore Sardinia (Sartori et al., 2004; Gaullier et al., 2014; Milia et al., 2017a). On the northern sector of the eastern Tyrrhenian margin (Tuscany, Elba) rift and supradetachment basins are controlled by NW-SE faults (Pascucci et al. 1999; Dini et al., 2002; Liotta et al., 2015). Along the Campania margin are present rift basin (Cosentino et al., 2006) and low-angle normal faults linked to a Messinian extension trending NE-SW (Schiattarella et al., 2006; Iannace et al., 2018). In northern Calabria the Squillace, Crotone and Sibari basins are controlled by E-W normal faults. On the contrary in southern Calabria a supradetachment basin bounded by approximately N-S structures is present offshore Stilo.

The overall pattern of extensional faults of the Central Mediterranean corresponds to normal faults striking parallel to the trench and normal faults striking at an oblique angle to the trench (Fig. 14). In particular in Campania and Calabria regions are present two rifts parallel to trench and an intervening rift orthogonal to the trench. A model that takes into account the formation of coeval orthogonal rift basins ("Double-door saloon tectonics") was proposed by Martin (2006). We maintain that the recognized Messinian rift basins can be interpreted according to the "Double-door saloon tectonics". In particular during subduction rollback, two arc-parallel rifts propagate in the opposite directions, from an initial central location, causing pairs of terranes to simultaneously rotate clockwise and anticlockwise. As the movement continues a gap begins to extend between them, and a third orthogonal rift initiates to form. A chief point is that Messinian extension resulted very rapid and evolved into two steps: between 6.0 and 5.6 Ma (400 Ka-long) and between 5.54 and $5.42 \mathrm{Ma}$ (120 Ka-long).

\section{Conclusion}

The stratigraphic analysis of the Messinian succession and the tectonic features of the Calabria area revealed some peculiar element of the geological evolution of the Central Mediterranean.

(i) The facies of the Messinian succession, that include mainly fine-grained deposits, suggest that the basins evolved in a more distal environment. This environmental feature together with the geographic position suggest that the basins are opened toward the Ionian Sea. 
(ii) The basins feature two orthogonal directions of extension. In the southernmost area the E-W extension developed consistently to the Serravallian-Tortonian rifting; whereas the central and northern basins extended in a N-S direction. Furthermore the region of Messinian extension resulted wider than that of the Serravallian-Tortonian extension.

(iii) The two ortogonal directions of extension are consistent with to double-door saloon kinematic model.

(iv) The Messinian rifting was associated to a major stage of opening of the Tyrrhenian Sea and records extreme rates of back arc extension. These rates were induced by the formation of a narrow subducting slab beneath the Ionian Sea that has undergone faster subduction rollback (Rosenbaum and Lister, 2004).

(v) The stratigraphic markers document that the Messinian tectonic evolution, characterized by two rifting stages, was very rapid. Consequently the abrupt physiographic change of the Central Mediterranean linked to extensional tectonics may have played a decisive role in the development of the Messinian salinity crisis.

Acknowledgments. We thank the Guest editor of this $O G S T$ issue, Dr Liviu Matenco, for inviting us to prepare this contribution. We acknowledge the useful review done by two anonymous referees. This study was funded by Universita' del Sannio (FRA 2017). We acknowledge IHS Inc. which provided the Kingdom software.

\section{References}

Amodio Morelli L., Bonardi G., Colonna V., Dietrich D., Giunta G., Ippolito F., Liguori V., Lorenzoni S., Paglionico A., Perrone V., Piccarreta G., Russo M., Scandone P., Zanettin Lorenzoni E., Zuppetta A. (1976) L'arco Calabro-Peloritano nell'orogene appenninico Maghrebide, Mem. Soc. Geol. Ital. 17, $1-60$.

Bonardi G., Cavazza W., Perrone V., Rossi S. (2001) CalabriaPeloritani terrane andnorthern Ionian Sea, in: Vai G.B., Martini I.P. (eds), Anatomy of an Orogen: The Apennines and Adjacent Mediterranean basins, Kluwer Academic Publishers, Dordrecht, pp. 287-306.

Braun J., Beaumont C. (1989) Contrasting styles of lithospheric extension: implications for differences between the Basin and Range Province and rift continental margins, in: Tankard A.J., Balkwill H.R. (eds), Extensional tectonics and stratigraphy of the North Atlantic margins. AAPG Memoir 46, pp. $53-79$.

Brosolo L., Mascle J., Loubrieu B. (2012) Morpho-bathymetry of the Mediterranean Sea, scale: 1:4000000, CGM/CGMW, UNESCO, Paris.

Buck W.R. (1991) Modes of continental extension, J. Geophys. Res. 96, 20161-20178.

Butler R.W.H., Lickorish W.H., Grasso M., Pedley H.M., Ramberti L. (1995) Tectonics and sequence stratigraphy in Messinian basins, Sicily: constraints on the initiation and termination of the Mediterranean salinity crisis, Geol. Soc. Am. Bull. 107, 4, 425-439.
Capozzi R., Artoni A., Torelli L., Lorenzini S., Oppo D., Mussoni P., Polonia A. (2012) Neogene to Quaternary tectonics and mud diapirism in the Gulf of Squillace (Crotone-Spartivento Basin, Calabrian Arc, Italy), Mar. Petrol. Geol. 35, 219-234.

Cavazza W., De Celles P.G. (1998) Upper Messinian siliciclastic rocks in southeastern Calabria (southern Italy): palaeotectonic and eustatic implications for the evolution of the central Mediterranean region, Tectonophysics 298, 223-241.

Chen Z., Schellart W.P., Duarte J.C. (2015) Overriding plate deformation and variability of fore-arc deformation during subduction: Insight from geodynamic models and application to the Calabria subduction zone, Geochem. Geophys. Geosyst. 16, 3697-3715, https://doi.org/10.1002/2015GC005958.

Clauzon G., Suc J.-P., Gautier F., Berger A., Loutre M.F. (1996) Alternate interpretation of the Messinian salinity crisis: Controversy resolved? Geology 24, 363-366.

Corti G., Ranalli G., Mulugeta G., Agostini A., Sani F., Zugu A. (2010) Control of the rheological structure of the lithosphere on the inward migration of tectonic activity during continental rifting, Tectonophysics 490, 165-172, https://doi.org/ 10.1016/j.tecto.2010.05.004.

Cosentino D., Federici I., Cipollari P., Gliozzi E. (2006) Environments and tectonic instability in central Italy (Garigliano Basin) during the late Messinian Lago-Mare episode: New data from the onshore Mondragone 1 well, Sed. Geol. 188-189, 297-317.

Dela Pierre F., Bernardi E., Cavagna S., Clari P., Gennari R., Irace A., Lozar F., Lugli S., Manzi V., Natalicchio M., Roveri M., Violanti D. (2011) The record of the Messinian salinity crisis in the Tertiary Piedmont Basin (NW Italy): the Alba section revisited, Palaeogeogr. Palaeocl. Palaeoecol. 310, 238-255.

Del Ben A., Barnaba C., Taboga A. (2008) Strike-slip systems as the main tectonic features in the Plio-Quaternary kinematics of the Calabrian Arc, Marine Geophysical Research 29, 1-12, https://doi.org/10.1007/s11001-007-9041-6.

Dini A., Innocenti F., Rocchi S., Tonarini S., Westerman D.S. (2002) The magmatic evolution of the Late Miocene laccolith-pluton-dyke granitic complex of Elba Island, Italy, Geological Magazine 139, 257-279. http://dx.doi.org/ 10.1017/S0016756802006556.

Di Nocera S., Ortolani F., Russo M., Torre M. (1974) Successioni sedimentarie messiniane e limite Miocene-Pliocene nella Calabria settentrionale, B. Soc. Geol. Ital. 93, 575-607.

Dunbar J.A., Sawyer D.S. (1989) How preexisting weaknesses control the style of continental breakup, J. Geophys. Res. 94, 7278-7292.

Faccenna C., Funiciello F., Civetta L., D'Antonio M., Piromallo C. (2007) Slab disruption, mantle circulation, and the opening of the Tyrrhenian basins, Geol. Soc. Am. Bull. SP 418, 153-169.

Gaullier V., Chanier F., Lymer G., Vendeville B., Maillard A., Thinon I., Lofi J., Sage F., Loncke L. (2014) Salt tectonics and crustal tectonics along the Eastern Sardinian margin: new insights from the «METYSS 1» cruise, Western Tyrrhenian, Tectonophysics, https://doi.org/10.1016/j.tecto.2013.12.015.

Ghisetti F., Vezzani L. (1981) Contribution of structural analysis to understanding the geodynamic evolution of the Calabrian Arc (Southern Italy), J. Struct. Geol. 3, 371-381.

Hilgen F.J., Krijgsman W., Langereis C.G., Lourens L.J., Santarelli A., Zachariasse W.J. (1995) Extending the astronomical (polarity) time scale into the Miocene, Earth Planet. Sci. Lett. 136, 3-4, 495-510. 
Horwáth F., Berckhemer H., Stegena L. (1981) Models of Mediterranean back-arc basin formation, Phil. Trans. R. Soc. A 300, 382-402, https://doi.org/10.1098/rsta.1981.0071.

Hsü K.J., Ryan W.B.F., Cita M.B. (1973) Late Miocene desiccation of the Mediterranean, Nature 242, 240-244.

Iannace P., Torrente M.M., Milia A. (2018) Tectonostratigraphic evolution of the Southern Campania margin: a key area for the evolution of the Tyrrhenian-Apennine system, Oil Gas Sci. Technol. - Rev. IFP Energies nouvelles, 73, 39

Jarsve E.M., Pedley A. (2012) Petroleum potential in the Gulf of Taranto, Search and discovery, Article \#10414 Posted June $25,2012$.

Jeanniot L., Kusznir N., Mohn G., Manatschal G., Cowie L. (2016) Constraining lithosphere deformation modes during continental breakup for the Iberia-Newfoundland conjugate rifted margins, Tectonophysics 680, 28-49, https://doi.org/ 10.1016/j.tecto.2016.05.006.

Kastens K.A., et al. (1987) Proceedings ODP Initial Reports, vol. 107, Ocean Drilling Program, College Station, TX, 999 p.

Knott S., Turco E. (1991) Late Cenozoic kinematics of the Calabrian Arc southern Italy, Tectonics 10, 1164-1172.

Krijgsman W., Hilgen F.J., Raffi I., Sierro F.J., Wilson D.S. (1999) Chronology, causes and progression of the Mediterranean salinity crisis, Nature 400, 652-655.

Liotta D., Brogi A., Meccheri M., Dini A., Bianco C., Ruggieri G. (2015) Coexistence of low-angle normal and high-angle strike- to oblique-slip faults during Late Miocene mineralization in eastern Elba Island (Italy), Tectonophysics 660, 17-34.

Lister G.S., Davis G.A. (1989) The origin of metamorphic core complexes and detachment faults formed during Tertiary continental extension in the northern Colorado River region, USA, J. Struct. Geol. 11, 65-94.

Malinverno A., Ryan W.B.F. (1986) Extension in the Tyrrhenian Sea and shortening in the Apennines as result of arc migration driven by sinking of the lithosphere, Tectonics $\mathbf{5}$, $227-245$.

Malinverno A., Cafiero M., Ryan W.B.F., Cita M.B. (1981) Distribution of Messinian sediments and erosional surfaces beneath the Tyrrhenian Sea: Geodynamic implications, Oceanol. Acta 4, 489-495.

Martin A.K. (2006) Oppositely directed pairs of propagating rifts in backarc basins: double saloon door seafloor spreading during subduction rollback, Tectonics 25, TC3008, https://doi.org/10.1029/2005TC001885.

Mascle J., Rehault J.-P. (1990) A revised seismic stratigraphy of the Tyrrhenian Sea: implications for the basin evolution, in: Kastens K.A., Mascle J., et al. (eds), Proceedings of the Ocean Drilling Program, Scientific Results, 10\%, Ocean Drilling Program, College Station, TX, pp. 617-634.

Massari F., Prosser G. (2013) Late Cenozoic tectono-stratigraphic sequences of the Crotone Basin: insights on the geodynamic history of the Calabrian arc and Tyrrhenian Sea, Basin Res. 25, 26-51, https://doi.org/10.1111/j.13652117.2012.00549.x.

Mattei M., Cipollari P., Cosentino D., Argentieri A., Rossetti F., Speranza F., Di Bella L. (2002) The Miocene tectonosedimentary evolution of the Southern Tyrrhenian Sea: stratigraphy, structural and paleomagnetic data from the onshore Amantea Basin (Calabrian Arc Italy), Basin Res. 14, 147-168.
Milia A., Torrente M.M. (2011) The possible role of extensional faults in localizing magmatic activity: A crustal model for the Campanian volcanic zone (eastern Tyrrhenian Sea, Italy), J. Geol. Soc. 68, 471-484.

Milia A., Torrente M.M. (2014) Early-stage rifting of the Southern Tyrrhenian region: The Calabria-Sardinia breakup, J. Geodyn. 81, 17-29, https://doi.org/10.1016/j.jog.2014.06.001.

Milia A., Torrente M.M. (2015a) Tectono-stratigraphic signature of a rapid multistage subsiding rift basin in the Tyrrhenian-Apennine hinge zone (Italy): A possible interaction of upper plate with subducting slab, J. Geodyn. 86, 42-60, https://doi.org/10.1016/j.jog.2015.02.005.

Milia A., Torrente M.M. (2015b) Rift and supradetachment basins during extension: Insight from the Tyrrhenian rift, $J$. Geol. Soc. 72, 5-8, https://doi.org/10.1144/jgs2014-046.

Milia A., Turco E., Pierantoni P.P., Schettino A. (2009) Fourdimensional tectonostratigraphic evolution of the southeastern peri-Tyrrhenian Basins (Margin of Calabria, Italy), Tectonophysics 476, 41-56.

Milia A., Torrente M.M., Mass B., Iannace P. (2013) Progressive changes in rifting directions in the Campania margin (Italy): new constrains for the Tyrrhenian Sea opening, Glob. Planet. Change 109, 3-17, https://doi.org/10.1016/j.gloplacha.2013. 07.003 .

Milia A., Torrente M.M., Tesauro M. (2017a) From stretching to mantle exhumation in a triangular backarc basin (Vavilov basin, Tyrrhenian Sea, western Mediterranean), Tectonophysics 710-711, 108-126, https://doi.org/10.1016/j.tecto.2016.10.017.

Milia A., Iannace P., Tesauro M., Torrente M.M. (2017b) Upper plate deformation as marker for the Northern STEP fault of the Ionian slab (Tyrrhenian Sea, central Mediterranean), Tectonophysics 710-711, 127-148, https://doi.org/10.1016/ j.tecto.2016.08.017.

Milia A., Valente A., Cavuoto G., Torrente M.M. (2017c) Miocene progressive forearc extension in the Central Mediterranean, Tectonophysics 710-711, 232-248, https://doi.org/ 10.1016/j.tecto.2016.10.002.

Milia A., Torrente M.M., Iannace P. (2017d) PlioceneQuaternary orogenic systems in Central Mediterranean: the Apulia-Southern Apennines-Tyrrhenian Sea example, Tectonics 36, 1614-1632, https://doi.org/10.1002/2017TC004571.

Minelli L., Faccenna C. (2010) Evolution of the Calabrian accretionary wedge (central Mediterranean), Tectonics 29, TC4004, https://doi.org/10.1029/2009TC002562.

Mitchum R.M., Vail P.R., Sangree J.B. (1977) Seismic stratigraphy and global changes of sea level, part 6: stratigraphic interpretation of seismic reflection patterns in depositional sequences, in: Payton C.E. (ed.), Seismic Stratigraphy Application to Hydrocarbon Exploration. Am. Ass. Petr. Geol. Memoir 26, pp. 117-133.

Monaco C., Tortorici L., Paltrinieri W. (1998) Structural evolution of the Lucanian Apennines, southern Italy, $J$. Struct. Geol. 20, 5, 617-638.

Panieri G., Polonia A., Lucchi R.G., Zironi S., Capotondi L., Negri A., Torelli L. (2013) Mud volcanoes along the inner deformation front of the Calabrian Arc accretionary wedge (Ionian Sea), Mar. Geol. 336, 84-98, https://doi.org/ 10.1016/j.margeo.2012.11.003.

Pascucci V., Merlini S., Martini I.P. (1999) Seismic stratigraphy of the Miocene-Pleistocene sedimentary basins of the northern Tyrrhenian Sea and western Tuscany, Basin Res. 11, 337-356. 
Rehault J.P., Mascle J., Fabbri A., Moussat E., Thommeret M., et al. (1987) The Tyrrhenian Sea before Leg 107, in: Kastens K.A., Mascle J., Auroux C., et al. (eds), 9-35.

Reitz M.A., Seeber L. (2012) Arc-parallel strain in a short rollback-subduction system: the structural evolution of the Crotone basin (northeastern Calabria, Southern Italy), Tectonics 31, TC4017, https://doi.org/10.1029/2011TC003031.

Roda C. (1964) Distribuzione e facies dei sedimenti Neogenici del Bacino Crotonese, Geolologica Romana 3, 319-366.

Rosenbaum G., Lister G.S. (2004) Neogene and Quaternary rollback evolution ofthe Tyrrhenian Sea, the Apennines, and the Sicilian Maghrebides, Tectonics 23, TC1013, https://doi.org/10.1029/2003TC001518.

Rossi S., Sartori R. (1981) A seismic reflection study of the external Calabrian arc in the northern Ionian Sea (eastern Mediterranean), Mar. Geophys. Res. 4, 403-426.

Roveri M., Gennari R., Lugli S., Manzi V., Minelli N., Reghizzi M., Riva A., Rossi M.E., Schreiber C.B. (2016) The Messinian salinity crisis: open problems and possible implications for Mediterranean petroleum systems, Petrol. Geosci., https://doi.org/10.1144/petgeo2015-089.

Sarti G. (1995) Controllo tettonico ed eustatico sulla deposizione delle unità del Miocene superiore della Val di Fine (Toscana, Pisa), Studi Geologici Camerti, Vol. Spec. 1995, 1, 581-592.

Sartori R. (1990) The main results of ODP Leg 107 in the frame of neogene to recent geology of Perityrrhenian areas, in: Kastens K.A., Mascle J., et al. (eds), Proceedings of the Ocean Drilling Program, Scientific Results 10\%, Ocean Drilling Program, College Station, TX, pp. 715-730.

Sartori R. (2003) The Tyrrhenian back-arc basin and subduction of the Ionian lithosphere, Episodes 26, 3, 217-221.

Sartori R., Torelli L., Zitellini N., Carrara G., Magaldi M., Mussoni P. (2004) Crustal features along a W-E Tyrrhenian transect from Sardinia to Campania Margins (Central Mediterranean), Tectonophysics 383, 171-192.

Schiattarella M., Di Leo P., Beneduce P., Giano S.I., Martino C. (2006) Tectonically driven exhumation of a young orogen: an example from the southern Apennines, Italy, in: Willet S.D., Hovius N., Brandon M.T., Fisher D.M. (eds), Tectonics, climate and landscape evolution, Penrose Conference Series, vol. 398, Geological Society of America Special Paper, Boulder, pp. 371-385.

Servizio Geologico d'Italia (2010) Foglio 561 S. Giovanni in Fiore-della Carta Geologica d'Italia alla scala 1:50.000, coordinatore Sarti M, Note illustrative, in: Moretti A., Vincenzi S., Vincenzi S. (eds), pp. 1-158.

Servizio Geologico d'Italia (2016) Foglio 580 Soverato della Carta Geologica d'Italia alla scala 1:50.000, coordinatore Paglionico, A., Note illustrative, in: Paglionico A., Festa F. (eds), pp. 1-88.

Spina V., Tondi E., Mazzoli S. (2011) Complex basin development in a wrench-dominated back-arc area: Tectonic evolution of the Crati Basin, Calabria, Italy, J. Geodyn. 51, 90-109, https://doi.org/10.1016/j.jog.2010.05.003.

Tansi C., Mut F., Critelli S., Iovine G. (2007) NeogeneQuaternary strike-slip tectonics in the central Calabrian Arc (southern Italy), J. Geodyn. 43, 393-414.

Torrente M.M., Milia A. (2013) Volcanism and faulting of the Campania margin (Eastern Tyrrhenian Sea, Italy): a threedimensional visualization of a new volcanic field off Campi Flegrei, Bull. Volcanol. 75, 6, 1-13, https://doi.org/10.1007/ s00445-013-0719-0.

Turco E., Maresca R., Cappadona P. (1990) La tettonica pliopleistocenica del confine calabro-lucano: Modello cinematico, Mem. Soc. Geol. Ital. 45, 519-529.

Turco E., Schettino A., Macchiavelli C., Pierantoni P.P. (2013) A plate kinematics approach to the tectonic analysis of the Tyrrhenian-Apennines System, Rend. Online Soc. Geol. Ital. 29, 187-190.

Vai G.B. (1992) Il segmento Calabro-Peloritano dell'orogene ercinico. Disaggregazione palinspastica, B. Soc. Geol. Ital. 111, 109-129.

Vai G.B. (1997) Cyclostratigraphic estimate of the Messinian Stage duration, in: Montanari A., Odin G.S., Coccioni R. (eds), Miocene stratigraphy - an integrated approach. developments in paleontology and stratigraphy 15, Elsevier, Amsterdam, pp. 463-476.

Van Dijk J.P. (1990) Sequence stratigraphy, kinematics and dynamic geohistory of the Crotone Basin (Calabrian Arc, Central Mediterranean): an integrated approach, Memoria Società Geologica Italiana 44, 259-285.

Van Dijk J.P. (1994) Late Neogene kinematics of intra-arc oblique shear-zone: thePetilia-Rizzuto fault zone (Calabrian Arc, Central Mediterranean), Tectonics 13, 1201-1230.

Van Dijk J.P., Okkes M. (1991) Neogene tectonostratigraphy and kinematics of Calabrian basins; implications for the geodynamics of the Central Mediterranean, Tectonophysics 196, 23-60.

Van Dijk J.P., Bello M., Brancaleoni G.P., Cantarella G., Costa V., Frixa A., Golfetto F., Merlini S., Riva M., Torricelli S., Toscano C., Zerilli A. (2000) A regional structural model for northern sector of the Calabrian Arc (southern Italy), Tectonophysics 324, 267-320.

ViDEPI (2009) Progetto Visibilità Dati Esplorazione Petrolifera in Italia.@ 2009-2010, Ministero dello Sviluppo Economico UNMIG, Società Geologica Italiana, Assomineraria (last accessed on 25.11.11, http://unmig.sviluppoeconomico.gov.it/videpi/)

Zecchin M., Civile D., Caffau M., Muto F., Di Stefano A., Maniscalco R., Critelli S. (2013) The Messinian succession of the Crotone Basin (southern Italy) I: Stratigraphic architecture reconstructed by seismic and well data, Mar. Petrol. Geol. 48, 455-473.

Ziegler P.A., Cloetingh S. (2004) Dynamic processes controlling evolution of rifted basins, Earth-Sci. Rev. 64, 1-50, https://doi.org/10.1016/S0012-8252(03)00041-2. 